\title{
Influence of Gamma Irradiation on DNA Methylation in Liver of Male Rats and their Offspring
}

\author{
M. KOŽURKOVÁ ${ }^{1}$, L. LETAVAYOVÁ ${ }^{2}$, E. MIŠÚROVÁ ${ }^{2}$ \\ P. J. Šafárik University, Faculty of Sciences, ${ }^{1}$ Institute of Chemistry, Department of Biochemistry, \\ ${ }^{2}$ Institute of Biological and Ecological Sciences, Department of Cellular Biology, Košice, Slovakia \\ Received November 28, 2006 \\ Accepted April 26, 2007
}

\begin{abstract}
Kožurková M., L. Letavayová, E. Mišúrová: Influence of Gamma Irradiation on DNA Methylation in Liver of Male Rats and their Offspring. Acta Vet. Brno 2007, 76: 215-222.

In the present work, the influence of gamma radiation ( $3 \mathrm{~Gy}$ ) on DNA methylation in slowly proliferating liver tissue of adult male rats and their offspring was studied. Total methylation of DNA was determined on the basis of presence of 5-methylcytosine at the inner cytosine of the C-C-G-G sequence by using restriction enzymes, endonuclease Msp I and its isoschisomer Hpa II. It was found that in the liver of control animals, molecular weight distribution of both Msp I and Hpa II digestion products of DNA and the level of DNA methylation were influenced by age mainly between the $3^{\text {rd }}$ and the $7^{\text {th }}$ days of life. At this time, significant difference was found especially in products of cleavage with enzyme Msp I, where an increase in DNA fragments of medium molecular weight $(1-7 \mathrm{~kb})$ occurred. The changes in the molecular weight distribution of DNA digestion products in the offspring of control rats were accompanied by an increase in the level of total DNA methylation from $29.8 \%$ to $67 \%$. In the offspring of irradiated males, the level of DNA methylation was higher in comparison with the offspring of non-irradiated control males, especially on the $3^{\text {rd }}$ day after birth. We suppose that this finding is conjoined with a transgeneration transfer of radiation-induced genome damage.
\end{abstract}

DNA methylation, aging, ionizing radiation, liver, parental generation, progeny

The advanced age of men and women is associated with an increased incidence of abnormal offspring. Because the father donates only chromatin to his offspring, the causal factor(s) for this effect must be of a genetic or epigenetic origin. The study of Oakes et al. (2003) revealed an epigenetic defect coupled with aging in the germ cells of male rats.

A candidate epigenetic mechanism that may be involved in male germ cell aging is DNA methylation. The presence of 5-methylcytosine $\left(\mathrm{m}^{5} \mathrm{C}\right)$ in the $\mathrm{CpG}$ dinucleotide sequence of somatic cell DNA commonly correlates with a decreased gene expression and is also implicated in the stability of chromosomes. Growing evidence links the presence of $\mathrm{m}^{5} \mathrm{C}$ to the recruitment of proteins to DNA that maintain chromatin in a stably repressed form (Volpe 2005). In this manner, patterns of DNA methylation separate the genome into transcriptionally active and inactive regions.

In mammals, the majority of cytosine bases are methylated at $\mathrm{CpG}$ sites. Genomic DNA is relatively $\mathrm{CpG}$-poor due to an accumulation of $\mathrm{m}^{5} \mathrm{C} \rightarrow$ thymine transitions. The regions, which are predominantly unmethylated, retain their $\mathrm{CpG}$ content and represent " $\mathrm{CpG}$ islands". CpG islands are commonly found in association with gene promoters (Oakes et al. 2003).

In general, DNA methylation is a key epigenetic control mechanism which is involved in a series of events. DNA methylation has been shown to be essential for healthy development (Serman et al. 2006; Antequera 2003; Oligny 2003), because it presents mechanisms for heritable silencing of the genes that control cellular proliferation (Jones 1996; B ay lin

\footnotetext{
Address for correspondence:

RNDr. Mária Kožurková, CSc.

Katedra biochémie

Ústav chemických vied

Prírodovedecká fakulta Univerzita P. J. Šafárika

Moyzesova 11

04167 Košice, Slovenská republika
}

Phone/fax: 020556222124

E-mail: kozurkom@kosice.upjs.sk

http://www.vfu.cz/acta-vet/actavet.htm 
et al. 1998; Kovařík et al. 2000), genome imprinting (Clayton-Smith 2003), $\mathrm{X}$-chromosome inactivation (Ke and Collins 2003) and suppression of parasitic DNA sequences ( Walsh et al. 1998). In connection with a high incidence of mutations induced by genotoxic agents, it is also interesting that DNA methylation can influence mutation rate (Rideout et al. 1990).

An increase in the mutation rate, which was observed after exposure of animals to genotoxic agents, is in great part due to induction of genome instability. Instability of the genome, which is induced by ionizing irradiation, can manifest itself by an increase in mutation frequency, chromosomal aberrations and other cytogenetic or biochemical alterations in some kinds of tissues of irradiated individuals (Beňová et al. 2003; Dvořák et al. 2006) long time after exposure or in somatic tissues of their progeny (Luke et al. 1997; Du brov a et al. 1998, 2000; Vorobtsova 2000; Kropáčová et al. 2002; Slovinská et al. 2004).

The aim of this work was to study the influence of ionizing irradiation on the fragmentation of DNA and the total level of DNA methylation in somatic cells, hepatocytes, of exposed male rats and their offspring. The methylation was estimated on the basis of analysis of DNA fragments obtained by treatment of isolated liver DNA with restriction enzymes Msp I and Hpa II in the typical methylation sequence C-C-G-G.

\section{Materials and Methods}

Male and female Wistar rats were used in the experiment (Central vivarium, P. J. Šafárik University, Košice, Slovak Republic). The animals were adapted to standard vivarium conditions (temperature $23 \pm 3^{\circ} \mathrm{C}$, relative humidity $60-70 \%$ ). Four to five animals were housed per cage. The age of the rats of the parental generation at the time of irradiation was 6 months; the age of the progeny at the time of analysis was 3 and 7 days $\left(F_{1}\right)$. The animals were fed MT diet (Top-Dovo, Dobrá Voda, Slovak Republic) and drank tap water ad libitum.

Males of the parental generation $\left(\mathrm{F}_{0}\right)$ were irradiated with a dose of $3 \mathrm{~Gy}$ of gamma radiation 25 days before mating with non-irradiated control females. With regard to the length of spermatogenesis, the parental exposure on day 25 before mating corresponds to the irradiation of the post-meiotic spermatids (Luke et al. 1997; Slovinská et al. 2004). The control group was represented by non-irradiated control male (5 animals), mated with nonirradiated control females ( 5 animals) and their progeny ( 7 animals).

The rat males were irradiated with a single whole body dose of 3 Gy by gamma rays from ${ }^{60}$ Co source (apparatus Chisostat, Czech Republic) at the dose rate of $0.23 \mathrm{~Gy} \cdot \mathrm{min}^{-1}$.

Isolation of rat liver chromosomal DNA was done by using DNeasy Tissue kit (Qiagen, Germany).

For restriction analysis we used two enzymes - Msp I and Hpa II (Moraxella species and Haemophilus parainfluenzae, respectively, MBI, Fermentas, Lithuania). Both enzymes cut DNA in the sequence:

,....5'...... ${ }^{\downarrow} \mathrm{C}$ GG......

............GG C $\uparrow \mathrm{C}$.......

However, Msp I and Hpa II differ in sensitivity to DNA methylation. Msp I cleaves outer and inner methylated cytosines ( ${ }^{\mathrm{m} C C G G}$ or $\mathrm{C}^{\mathrm{m}} \mathrm{CGG}$ ), while Hpa II cleaves only outer cytosines in this DNA sequence (CCGG). On this base we could determine percentage of methylated fragments of genome DNA.

The samples of DNA were analyzed in 1\% agarose gel in TAE (Tris-HCl, EDTA, sodium acetate) containing ethidium bromide (at final concentration $1 \mathrm{mg} / \mathrm{ml}$ ) ( Sambrook et al. 1989). For gel preparations we used the agarose type II-A, A-9918 Medium EEO (Sigma, USA). BenchTop 1 kb DNA Ladder 250 - 10000 (Promega, USA) was used as a standard. The electrophoresis went along at $100 \mathrm{~mA}(75 \mathrm{~V})$ for 3 hours. Individual fragments of DNA have been detected by UV light (UV-transilluminator, Upland, USA).

Photographic documentation was done by the digital camera OLYMPUS 400. For densitometrical scanning of DNA preparations and data evaluation we used the software Microsoft Photo Editor, Microsoft Excel, UTHSCSA Image Tool, XnView and GraFit 4.

\section{Results}

Representative electrophoreogram of liver DNA sample of 3-day-old offspring is demonstrated in Fig. 1 (see Plate IV).

Electrophoreograms of non-digested DNA and DNA that was digested with Msp I or Hpa II were scanned densitometrically. The scans were divided into molecular weight intervals calculated from the migration of the standard DNA.

On densitometrical scans, curves of non-digested DNA and DNA treated by the restriction 
enzymes had different shapes. The shape of curves was influenced also by the age of animals and by irradiation of males of parental generation.

In non-digested samples of control males and their progeny, the bulk of the isolated DNA was concentrated in the band with a maximum at $8-10 \mathrm{~kb}$, whereas in the samples of irradiated males and their progeny, a considerable part of DNA was present also in areas with higher electrophoretic mobility. This effect of irradiation was most marked in the nondigested samples of DNA isolated from the liver of 3-day-old progeny (Fig. 2 A, B). In 7day-old progeny and mainly in males of parental generation, the difference between control and irradiated non-digested samples of DNA disappeared (results not shown).

On the basis of densitometrical scans, molecular weight distribution of products of DNA cleavage with restriction enzymes Msp I and Hpa II was calculated.

A

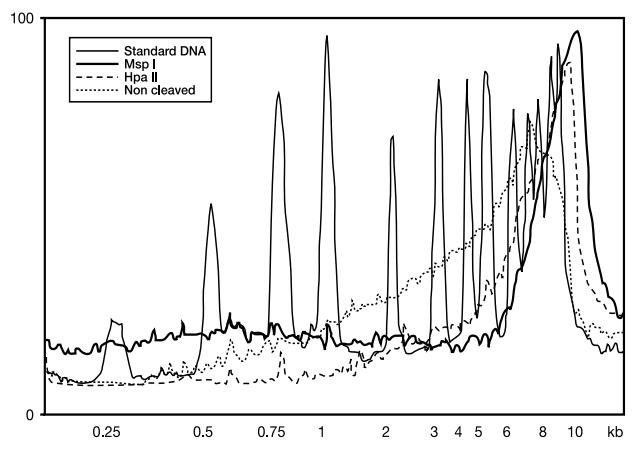

B

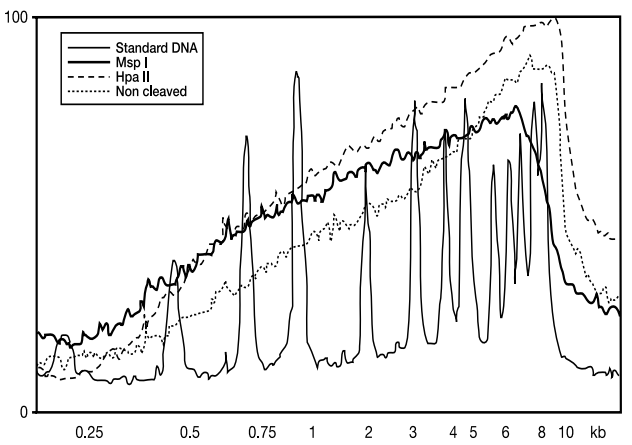

Fig. 2. Densitometer scans of non-digested and Msp I and Hpa II digested liver DNA of 3-day-old offspring of control rats (A) and irradiated rats (B).

Molecular weight distribution of DNA digested with both Msp I and Hpa II was influenced by age in control animals mainly between the $3^{\text {rd }}$ and $7^{\text {th }}$ days of life (Figs 3 and 5, respectively). Significant difference was found especially in products of cleavage with enzyme Msp I, where an increase in DNA fragments of medium molecular weight $(1-7 \mathrm{~kb})$ occurred between the $3^{\text {rd }}$ and $7^{\text {th }}$ days of life. The curves of weight distribution of DNA cleaved by both enzymes in the control 7-day-old young resembled the curves of adult 6-month-old males of parental generation (Figs 5 and 7, respectively).

Irradiation by the dose of $3 \mathrm{~Gy}$ did not induce significant changes in the molecular weight distribution of restriction fragments of DNA isolated from exposed males of parental generation or from their 7-day-old young (Figs 8 and 6, respectively), but in the 3-day-old young, a strong shift of distribution towards intermediate region of molecular weight fragments in comparison with appropriate control values was observed (Fig. 4).

The results of analyses of DNA fragments obtained by treatment with the restriction enzymes Msp I and Hpa II, summarized in Table 1, showed that the total level of DNA methylation was influenced not only by age but also by irradiation. Age-related alterations in liver DNA methylation in the sequence C-C-G-G were expressed mostly between the $3^{\text {rd }}$ and $7^{\text {th }}$ days of life (increase from $30 \%$ to $67 \%$ ); from the $7^{\text {th }}$ day until the $6^{\text {th }}$ month of age (parental males), the increase in total DNA methylation was substantially slower (increase from $67 \%$ to $82 \%$ ). Effect of irradiation of males of parental generation was most markedly expressed in 3-day-old progeny (48\% of methylated DNA in progeny of irradiated males comparing to $30 \%$ in progeny of control males). In the 7-day-old progeny and in exposed males of parental generation themselves, the difference in total DNA methylation in 


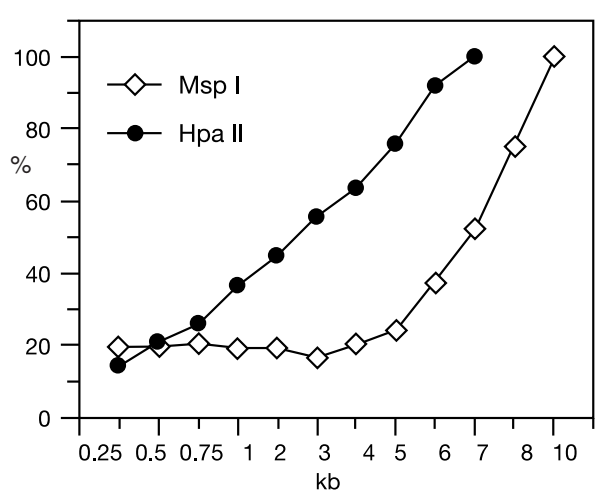

Fig. 3. Molecular weight distributions of liver DNA of 3-day-old offspring of control males after digestion with Msp I and Hpa II.

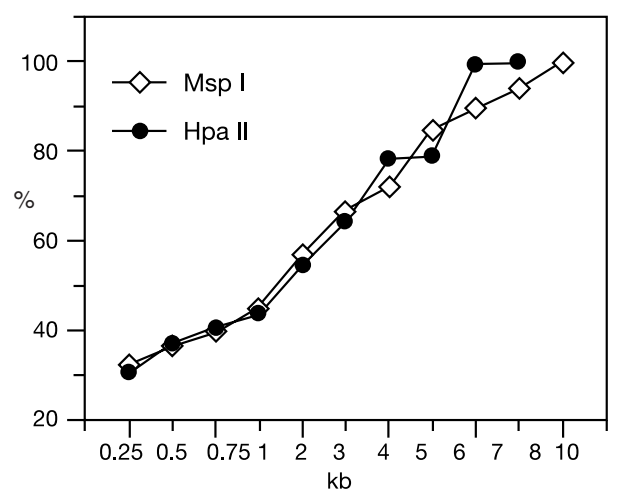

Fig. 5. Molecular weight distributions of liver DNA of 3-day-old offspring of irradiated males after digestion with Msp I and Hpa II.

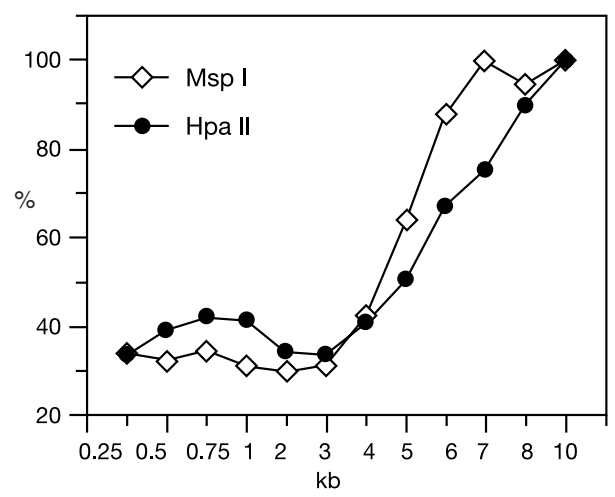

Fig. 7. Molecular weight distributions of liver DNA of adult control males of parental generation after digestion with Msp I and Hpa II.

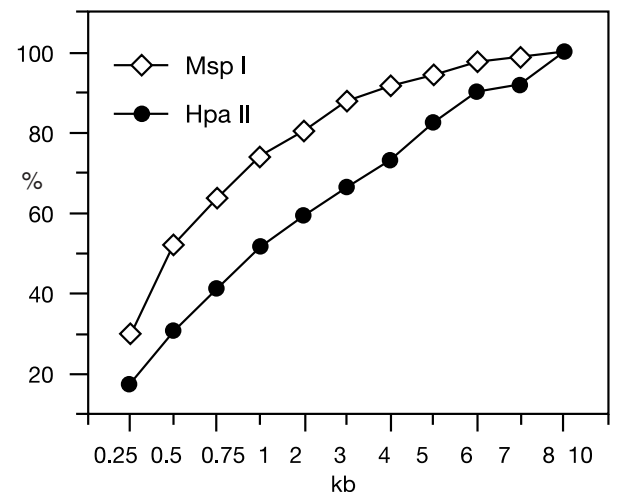

Fig. 4. Molecular weight distributions of liver DNA of 7-day-old offspring of control males after digestion with Msp I and Hpa II.

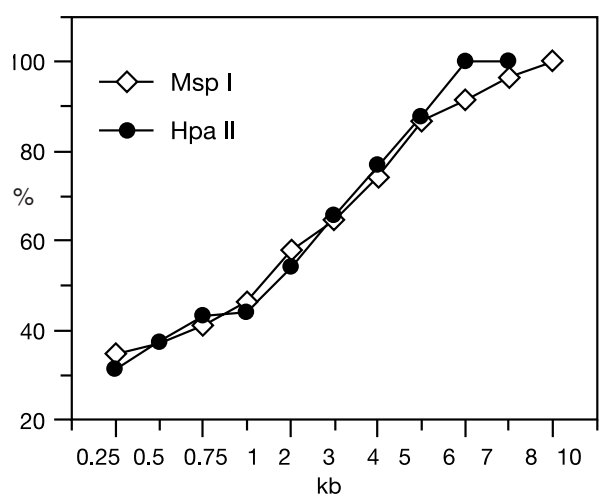

Fig. 6. Molecular weight distributions of liver DNA of 7-day-old offspring of irradiated males after digestion with Msp I and Hpa II.

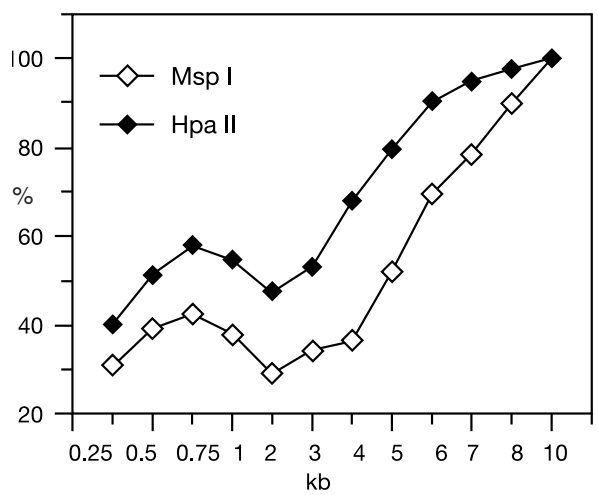

Fig. 8. Molecular weight distributions of liver DNA of adult irradiated males of parental generation after digestion with Msp I and Hpa II. 
Table 1. The mass average molecular weight (Mw), the number average molecular weight (Mn), the ratio $\mathrm{Mw} / \mathrm{Mn}$ (r) and percentage of methylation (\%) in liver DNA of control and irradiated male rats (3 Gy) and their offspring

\begin{tabular}{|c|c|c|c|c|c|}
\hline & & $\mathrm{Mw}(\mathrm{kb})$ & $\mathrm{Mn}(\mathrm{kb})$ & $\mathrm{r}$ & $\%$ methylation \\
\hline Control & $\begin{array}{l}\text { Msp I } \\
\text { 3- days-old } \\
\text { 7- days-old } \\
\text { parental } \\
\text { generation } \\
\text { Hpa II } \\
\text { 3- days-old } \\
\text { 7- days-old } \\
\text { parental } \\
\text { generation }\end{array}$ & $\begin{array}{l}3.08 \\
2.50 \\
\\
3.07 \\
\\
3.77 \\
3.70 \\
\\
2.20\end{array}$ & $\begin{array}{l}0.87 \\
0.67 \\
0.84 \\
\\
0.67 \\
1.00 \\
\\
1.01\end{array}$ & $\begin{array}{r}3.50 \\
3.70 \\
\\
3.60 \\
\\
3.73 \\
3.70 \\
\\
\\
2.16\end{array}$ & $\begin{array}{l}29.8 \\
67.0 \\
82.0\end{array}$ \\
\hline Irradiated & $\begin{array}{l}\text { Msp I } \\
\text { 3- days-old } \\
\text { 7- days-old } \\
\text { parental } \\
\text { generation } \\
\text { Hpa II } \\
\text { 3- days-old } \\
\text { 7- days-old }\end{array}$ & $\begin{array}{l}3.75 \\
3.73 \\
2.25 \\
\\
3.70 \\
3.69\end{array}$ & $\begin{array}{l}0.47 \\
0.69 \\
0.75 \\
\\
0.97 \\
1.00\end{array}$ & $\begin{array}{l}7.90 \\
5.40 \\
2.90 \\
\\
3.81 \\
3.69\end{array}$ & $\begin{array}{l}48.4 \\
69.0 \\
82.0\end{array}$ \\
\hline
\end{tabular}

The mass average molecular weight $\mathrm{M}_{\mathrm{w}}=\Sigma \mathrm{W}_{\mathrm{i}} \times \mathrm{M}_{\mathrm{i}}$, where $\mathrm{W}_{\mathrm{i}}$ is the mass fraction and $\mathrm{M}_{\mathrm{i}}$ the average weight for interval i. Individual intervals were obtained from gel photographs, which were scanned; scans were divided into molecular weight intervals calculated from the migration of standard DNA molecules. The area under each interval was measured and the molecular weight midpoint was used as the average molecular weight for the intervals.

The number average molecular weight $M_{n}=\Sigma X_{i} \times M_{i}$, where $X_{i}$ is number fraction for interval $i$. For the number average distribution, the relative number of molecules under each interval was summed and the number in each interval of molecules was taken as a fraction of the total DNA.

$r$ is the ratio $r=M_{w} / M_{n}$ a change in the value of $r$ indicated a change in the shape of the distribution.

Percentage of methylation is calculated as \% methylation $=1-\left(\mathrm{M}_{\mathrm{n} \mathrm{Msp} \mathrm{I}}\right) /\left(\mathrm{M}_{\mathrm{n} \mathrm{Hpa} \mathrm{II}}\right) \times 100$.

comparison with appropriate control values was small or none (67\% in comparison with $69 \%$, and $82 \%$ in comparison with $82 \%$, respectively).

\section{Discussion}

The study of the total level of DNA methylation in the liver of control and irradiated adult rat males and their young was based on the fact that both restriction enzymes, Msp I and Hpa II, cleaved DNA in the C-C-G-G sequence, but only Msp I cleaved the methylated version C- ${ }^{\mathrm{m}} \mathrm{C}-\mathrm{G}-\mathrm{G}$. Kunnath and Locker (1982) found that neither hemimethylated nor doubly methylated duplex DNA was a good substrate for cleavage by Hpa II, while unmethylated DNA was cleaved completely. This experiment demonstrated directly that Hpa II did not cut DNA methylated on one or both strands at the internal cytosine of C-C-G-G sequence. Such site specificity has been previously shown by indirect experiments (Bird and Southern 1978; Gruenbaum et al. 1981). Thus, comparison of the molecular weight distribution of DNA cleaved with each of these enzymes enabled quantification of methylation in this typical methylation sequences.

In our experiments, analyses of molecular weight distributions of DNA in control animals indicated that between the $3^{\text {rd }}$ and $7^{\text {th }}$ days of life there were profound changes in DNA 
fragments after treatment with both Msp I and Hpa II. Especially interesting was an increase in medium-sized fractions $(1-7 \mathrm{~kb})$ in Msp I products of DNA digestion between the $3^{\text {rd }}$ and $7^{\text {th }}$ days of life. This finding, similarly to percentage of methylation (calculated from the molecular weight distribution of DNA fragments) indicated a marked increase in the level of total DNA methylation in the liver of laboratory rats during early days of postnatal life. The increase in total DNA methylation was accompanied by a profound decrease in the proliferation rate of liver cells ( Š an ová et al. 2004).

Our results in non-irradiated adult rat males of parental generation are comparable to the results of Kunnath and Locker (1982) in Wistar-Furth and Sprague-Dawley rats. In their experiment, mass average distribution of adult liver DNA digested with Msp I was equal to $3.21 \mathrm{~kb}$ and total methylation of DNA to $76 \%$ (in our experiment $3.07 \mathrm{~kb}$ and $82 \%$, respectively). For DNA isolated from other tissues, these authors gave the values of total methylation in the range from 45 to $79 \%$.

Oakes et al. (2003) found in Brown-Norway rats that age-dependent changes in DNA methylation may differ between non-proliferating cells of old tissues and the cells of tissues that are renewed within an old individual. Age-dependent alterations of DNA methylation have been observed not only in normal mammalian somatic cells but also in age-related diseases (Bird 2002).

Some effects of ionizing radiation are similar to changes occurring in the process of aging (Kožurková et al. 1993, 1995); therefore we expected alterations of DNA methylation also after irradiation with gamma rays. It was interesting that the curves of molecular weight distribution and the total levels of DNA methylation in the liver of rat males of parental generation that were irradiated by the dose of $3 \mathrm{~Gy}$, indicated no alterations in comparison with non-irradiated control males. On the contrary, the effect of irradiation manifested itself in the progeny of exposed animals, mainly on the $3^{\text {rd }}$ postnatal day, by alteration in molecular weight distribution of DNA cleaved by enzymes Msp I and Hpa II and by increase in total DNA methylation. The percentage of DNA methylation in the liver of control male progeny ranged from $30 \%$ to $67 \%$, with the average value of $48 \%$ and in the liver of irradiated male progeny ranged from $48 \%$ to $69 \%$, with the average value of $58 \%$.

The higher level of DNA methylation observed in the 7-day-old progeny of control males (compared with 3-day-old young) and already in the 3-day-old progeny of irradiated males was probably connected with inhibition of proliferative activity of hepatocytes, but it could also accompany alterations in the gene expression. In parallel experiments, Ša nová et al. (2004, 2005) found a decrease in proliferative activity and multiple increases in chromosomal aberration frequency in the embryos and young of rat males irradiated with the same dose ( $3 \mathrm{~Gy}$ ) of gamma radiation.

Besides the examination of DNA methylation, which was performed on the basis of analysis of DNA cleaved with the restriction enzymes Msp I and Hpa II, also radiation fragmentation of non-cleaved DNA was monitored. We have found that in the non-cleaved DNA samples, isolated from 3-day-old progeny of irradiated males, the fraction of low molecular fragments (to $4000 \mathrm{~kb}$ ) increased in comparison to the same age progeny of the control males. This finding is in accordance with results of Blagoi et al. (1994), who studied DNA isolated from the liver of rats continuously exposed to ionizing radiation in the region of Chernobyl nuclear power station and observed a gradual rise in the low molecular DNA fraction in successive generations of progeny.

We assume that these findings, mainly those concerning increased fragmentation of DNA (non-cleaved by restriction enzymes) isolated from the progeny of irradiated males, give an indirect evidence of transmission of radiation-induced DNA damage from irradiated individuals to their progeny. 


\section{Vplyv gama žiarenia na metyláciu DNA v pečeni samcov potkanov a ich potomkov}

V práci sme študovali vplyv gama žiarenia (3 Gy) na hladinu metylácie DNA v pomaly proliferujúcom tkanive pečene dospelých samcov potkanov a ich potomkov. Celková metylácia DNA bola určená na základe prítomnosti 5-metylcytozínov vo vnútri sekvencií C-C-G-G použitím restrikčných enzýmov, endonukleázy Msp I a jeho izoschizoméru Hpa II. Zistili sme, že v pečeni kontrolných zvierat, distribúcia molekulových hmotností Msp I a Hpa II štiepnych produktov DNA a hladina DNA metylácie boli ovplyvnené vekom hlavne medzi 3. a 7. dňom života. V tomto čase signifikantné rozdiely sme našli hlavne v produktoch štiepenia enzýmom Msp I, kde sme pozorovali zvýšenie množstva fragmentov DNA strednej molekulovej hmotnosti (1-7 kb). Zmeny v distribúcii molekulovej hmotnosti produktov štiepenia DNA v pečeni potomkov kontrolných potkanov boli sprevádzané zvýšením celkovej hladiny metylácie DNA z 29,8 \% na $67 \%$. U potomkov ožiarených samcov, hladina metylácie DNA bola vyššia v porovnaní s potomkami neožiarených kontrolných samcov, hlavne na 3. deň po narodení. Predpokladáme, že tieto nálezy súvisia s transgeneračným prenosom žiarením-indukovaného poškodenia genómu.

\section{Acknowledgements}

The work was supported by the grant of Ministry of Education VEGA 1/2353/05 and VEGA 1/3254/06. The experiment was conducted according to the principles in Act No. 289/2003 and 489/2003 of Slovak Republic for the Care and Use of Laboratory Animals.

\section{References}

ANTEQUERA F 2003: Structure, function and evolution of CpG island promoters. Cell Mol Life Sci 60: 16471658

BAYLIN SB, HERMAN JG, GRAFF JR, VERTINO PM, ISSA JP 1998: Alteration in DNA methylation: a fundamental aspect of neoplasia. Adv Cancer Res 72: 141-196

BEŇOVÁ K, TOROPILA M, FALIS M, DVOŘÁ, P 2003: Influence of ionising radiation on the activity of selected adaptive enzymes in chickens and rats. Acta Vet Brno 72: 201-205

BIRD A, SOUTHERN EM 1978: Use of restriction enzymes to study eukaryotic DNA methylation: I. The methylation pattern in ribosomal DNA from Xenopus laevis. J Mol Biol 118: 27-47

BIRD A 2002: DNA methylation patterns and epigenetic memory. Genes Dev 16: 6-21

BLAGOI YP, KORNILOVA SV, LEONTEV VS, SOROKIN VA, GLADCHENKO GO, VALAYEV VA, GRIGOREV DN, KAPINOS LY, BONDARENKO VN, KOLOD VY 1994: Structural and physicochemical characteristics of DNA of animal tissue exposed to prolonged chronic irradiation in the Chernobyl zone. Biophysics 39: 641-649

CLAYTON-SMITH J 2003: Genomic imprinting as a cause of disease. BMJ 327: 1121-1122

DUBROVA YE 2003: Radiation-induced transgenerational instability. Oncogene 22: 7087-7093

DVOŘ́K P, ŠALPLACHTA J, ZIMA S,GROLICHOVÁ M, MUSILOVÁ H 2006: Effect of ionizing radiation on tissue enzymes in pig liver and kidneys. Bull Vet Inst Pulawy 50: 221-223

GRUENBAUM Y, NAVEH-MANY T, CEDAR H, RAZIN A 1981: Restriction enzyme digestion of hemimethylated DNA. Nucleic Acids Res 9: 2509-2515

JONES P A 1996: DNA methylation errors and cancer. Cancer Res 56: 463-2467

KE X, COLLINS A 2003: CpG islands in human X-inactivation. Ann Hum Genet 67: 242-249

KOVǍ̌́IK A, KOUKALOVÁ B, LIM KY, MATYÁŠEK R, LICHTENSTEIN CP, LEITCH AR, BEZDĚK M 2000: Comparative analysis of DNA methylation in tobacco heterochromatic sequences. Chromosome Res 8: $527-541$

KOŽURKOVÁ M, MIŠÚROVÁ E, KROPÁČOVÁ K 1993: Aging and radiation induced alterations of histones in regenerating rat liver. Mech Ageing Dev 72: 37-48

KOŽURKOVÁ M, MIŠÚROVÁ E, KROPÁČOVÁ K 1995: Effect of aging and gamma radiation on acetylation of rat liver histones. Mech Ageing Dev 78: 1-14

KROPÁČOVÁ K, SLOVINSKÁ L, MIŠÚROVÁ E 2002: Cytogenetic changes in the liver of progeny of irradiated male rats. J Radiat Res (Tokyo) 43: 125-133

KUNNATH L, LOCKER J 1982: Characterization of DNA methylation in the rat. Biochem Biophys Acta 699: 264-271

LUKE GA, RICHES AC, BRYANT PE 1997: Genomic instability in haematopoietic cells of $\mathrm{F}_{1}$ generation mice of irradiated male parents. Mutagenesis 12: 147-152

OAKES CC, SMIRAGLIA DJ, PLASS C, TRASLER JM, ROBAIRE B 2003: Aging results in hypermethylation of ribosomal DNA in sperm and liver of male rats. Proc Natl Acad Sci USA 100: 1775-1789 
OLIGNY LL 2003: Cancer and epigenesist: a developmental perspective. Adv Pediatr 50: 59-80

RIDEOUT WMI, COETZEE GA, OLUMI AF, JONES PA 1990: 5- Methylcytosine as an endogenous mutagen in the human LDL receptor and p53 genes. Science 249: 1288-1290

SAMBROOK J, FRITCH E, MANIATIS T 1989: Molecular cloning: a laboratory manual (DNA methylation) Cold Spring Harbor Laboratory Press 5.31-5.32

SERMAN A, VLAHOVIC M, SERMAN L, BULIC-JAKUS F 2006: DNA methylation as a regulatory mechanism for gene expression in mammals. Coll Antropol 30:665-71

SLOVINSKÁ L, ELBERTOVÁ A, MIŠÚROVÁ E 2004: Transmission of genome damage from irradiated male rats to their progeny. Mutat Res 559: 29-37

ŠANOVÁ Š, BÁLENTOVÁ S, SLOVINSKÁ L, MIŠÚROVÁ E 2005: Effects of preconceptional gamma irradiation on the development of rat brain. Neurotoxicol Teratol 27: 145-151

ŠANOVÁ Š, KROPÁČOVÁ K, SLOVINSKÁ L, MIŠÚROVÁ E: Cytogenetic changes in different organs of the progeny of irradiated male rats (In Slovak). In: BEŇOVÁ et al. (Eds). The second conference of radiobiology, 24 June 2004, Slovak Republik, Košice, pp. 128-145

VOLPE P 2005: The language of methylation in genomic of eukaryotes. Biochemistry (Mosc.) 70: 584-595

VOROBTSOVA IE 2000: Irradiation of male rats increases the chromosomal sensitivity of progeny for genotoxic agents. Mutagenesis 15: 33-38

WALSH CP, CHAILLET JR, BESTOR TH 1998: Transcription of LAP endogenous retroviruses is constrained by cytosine methylation. Nat Genet 20: 16-117 
Plate IV

Kožurková M. et al.: Influence of Gamma ....pp. 215-222

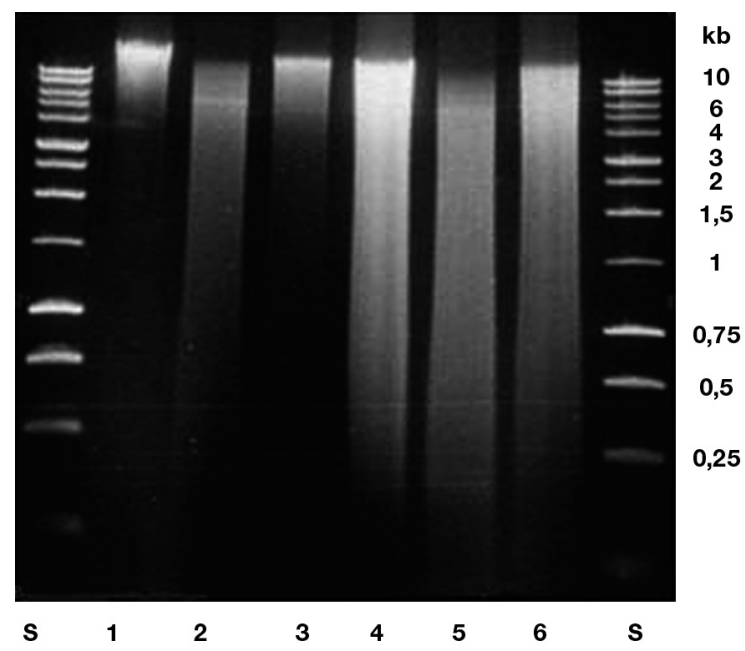

Fig. 1. Non-digested and Msp I or Hpa II digested chromosomal DNA isolated from livers of 3day-old offspring of control and irradiated ( $3 \mathrm{~Gy}$ ) male rats (separated in $1 \%$ agarose gel).

Samples were placed in the gel in this order: S - standard DNA $1 \mathrm{~kb}(3 \mu \mathrm{l}), 1$ - control non-digested sample $(3 \mu \mathrm{l}), 2$ - control sample digested with Msp I (10 $\mu \mathrm{l}), 3$ - control sample digested with Hpa II $(10 \mu \mathrm{l}), 4$ irradiated non-digested sample $(3 \mu \mathrm{l}), 5$ - irradiated sample digested with Msp I $(10 \mu \mathrm{l}), 6$ - irradiated sample digested with Hpa II (10 $\mu \mathrm{l}), \mathrm{S}$ - standard DNA. 